\title{
Antibacterial Effects of Eisenia fetida, Earthworm Extract against Pathogenic Bacteria Isolated from Cyprinus carpio
}

\author{
Nitish Bansal $^{1 *}$, Rajender Kumar Gupta ${ }^{1}$ and Vikas Nehra ${ }^{2}$ \\ ${ }^{1}$ Department of Zoology and Aquaculture, Chaudhary Charan Singh Haryana Agricultural \\ University, Hisar (Haryana) - 125004, India \\ ${ }^{2}$ Department of Veterinary Pathology, Lala Lajpat Rai University of Veterinary and Animal \\ Sciences, Hisar (Haryana) - 125004, India \\ *Corresponding author
}

\section{A B S T R A C T}

In the present investigations, whole body extract of earthworm, Eisenia fetida was tested for antibacterial activity against fish bacterial pathogens. The bacteria were isolated from different tissues of infected common carp, Cyprinus carpio and identified by gram staining method. A total of eight pathogenic bacteria were isolated. Antimicrobial activity of the extract was studied under in vitro conditions by well diffusion assay. The extract of Eisenia fetida showed antibacterial activity against all the pathogenic bacteria and the maximum zone of inhibition was observed against A. hydrophila. Histological investigations had revealed that feeding the fish on a diet prepared by incorporating earthworm extract resulted in an increase in intestinal folds while injecting the fish with $A$. hydrophila resulted in degeneration and desquamatation of intestinal epithelium feeding on supplementary diet. When a healthy carp was injected with pathogenic bacterium and also fed on a diet prepared in earthworm extract, it resulted in a significant $(\mathrm{P}<0.05)$ increase in intestinal folds, intestinal microvilli, increase in concentration of melano-macrophage centre and also haemopoietic tissue in the kidneys. From these studies, it was concluded that the earthworm extract possesses very strong antibacterial properties which could be employed in treating bacterial infections in fishes, leading to the availability of antibiotic free fishes to the consumers.

\section{Introduction}

Fishery is an important sector in India as it provides employment to millions of people and also contributes to the food security of the country. Massive fish mortalities have been reported from different countries due to bacterial, fungal, viral and protozoan infections/diseases that results in heavy economic losses. A variety of Bacterial infections pose significant threats to successful fish production throughout the world.

Diseases as well as environmental pollution play an important role in aquaculture growth. Bacterial diseases outbreaks impose a significant constraint in fish and shellfish production (Bachere et al., 1995; Verschuere et al., 2000; Gomez et al., 2007). Bacterial 
pathogens have been reported to cause heavy mortality in both cultured and wild fish species in different parts of the world (Bader et al., 2003; Joseph and Clerk, 2002). Use of antimicrobial drugs in aquaculture has led to the emergence of many antibiotic resistant bacteria (Schwarz et al., 2001; Akinbowale et al., 2006).

Biological active compounds extracted from earthworms has traditionally been used by indigenous people throughout the world, more particularly in Asia, including India, Myanmar, China, Korea and Vietnam (Ranganathan, 2006). Since long time, earthworms have been used as a therapeutic drug source in China and other parts of the Far East countries (Ismail, 2005). Studies have shown the antipyretic, antispasmodic, detoxic, diuretic, antihypertensive, antiallergic, anticoagulative, antiasthmatic, spermatocidal, antioxidative, antimicrobial, anticancer, antiulceral and anti-inflammatory activities particularly of biologically active compounds isolated from earthworms (Hrzenjak et al., 1998; Wang et al., 2007; John and Packialakshmi, 2007; Balamurugan et al., 2009; Cooper and Balamurugan, 2010; Ansari and Sitaram, 2010). Prakash et al., (2007) and Balamurugan et al., (2007) have reported the presence of anti-ulceral and anti-oxidative properties in the paste of Lampito mauritii. Histopathological studies are recognized as biomarkers in the evaluation of the health of fish exposed to contaminants/pathogenic microbes/metazoan parasites, both in the laboratory (Thophon et al., 2003) and field studies. The histopatological studies on various target organs like intestine, gill, kidney and liver are useful to assess the damage to fish and animal health.

A number of studies have been carried out by researchers across the globe for assessing and evaluating the antibacterial activity of earthworm extract in many animal species.
However, not many attempts have been made to study this extra-ordinary property of earthworms in fish health management. In order to scientifically analyze some of the ethnomedical uses of earthworm, the present investigation was undertaken to analyze the antibacterial properties of earthworm extract and its use in fish health management.

\section{Materials and Methods}

\section{Collection of samples}

Both healthy and infected specimens of Cyprinus carpio were obtained from fish farms in Hisar (Haryana) and brought to the Fish Biotechnology Laboratory of the Department of Zoology, CCS Haryana Agricultural University, Hisar (India). The earthworm, Eisenia fetida were collected from the vermicomposting Unit of the Department of Zoology, Chaudhary Charan Singh Haryana Agricultural University, Hisar.

\section{Isolation of bacteria}

Tissue samples from skin lesions, gills and intestine were dissected out from both healthy and infected common carp. Tissues were homogenized in Phosphate buffer saline (PBS) and then centrifuged at $12000 \mathrm{rpm}$ for $10 \mathrm{~min}$. Supernatant was spread over the nutrient agar (NA) medium under laminar flow. Plates were incubated in BOD incubator maintained at 30 $\pm 2^{\circ} \mathrm{C}$ for $18-24$ hours. Growth on NA plate was observed after 18-24 h. Pure colonies of bacteria were isolated by further sub-culturing of single colonies on NA plates (Gerhardt et al., 1994).

\section{Identification of bacteria}

Isolated pure cultures of bacteria were subjected to biochemical tests (primary and secondary tests) for identification as following Krieg and Holt (1984) in “Bergey's Manual of 
Determinative Bacteriology". Identification of bacteria was done with the help of computer program, PIBWin (Website: www.soton.ac. in.uk/tnb/pib.htm).

\section{In vivo pathogenicity testing}

Healthy common carp (weighing about 20$25 \mathrm{~g}$ ) were collected from the fish farms and brought to the laboratory. The fish were acclimated for one week at ambient temperature in the laboratory and fed on supplementary diet. In vivo pathogenicity test was carried out on healthy fish by a method described by Keskin et al., (2004).

\section{Preparation of earthworm extract}

Sexually mature clitellated earthworms (Eisenia fetida) were washed with running tap water and then fed with wet blotting paper for 18-20 hours for gut clearance. These worms were again washed with distilled water. In order to kill the worms they were kept in plastic trough covered with polythene in sunlight for three days.

Mucus and coelomic fluid that oozed out formed a brown coloured paste called earthworm paste. After mastication of whole earthworm obtained with mucus and coelomic fluid, a brown coloured paste was formed (Balamurugan et al., 2007). After dried the paste in incubator, it was mixed with nuclease free water and centrifuged the whole mixture at $12000 \mathrm{rpm}$ for $10 \mathrm{~min}$. The supernatant was used as aqueous earthworm extract. The $95 \%$ ethanolic extract of earthworm were also prepared using aqueous extract in different combination.

\section{Preparation of feed}

During the experiment the fingerlings of common carp were acclimatized for 15 days under laboratory conditions and fed with the normal diet. After 15 days the experiments were conducted by feeding fish with normal diet and diet containing earthworm extract. The normal diet was prepared by using the following composition:

The extract was weighed on electronic balance ( $1.0 \%, 1.5 \%$ and $2.0 \%$ of the total feed gradients. Feed ingredients were mixed with the paste/ extract of earthworms and then the pellets of feed were prepared. All ingredients were mixed well and then dough was made by wetting with sterilized double distilled water. Pellets were obtained by pelletizer and then dried in BOD at $55{ }^{\circ} \mathrm{C}$ temperature.

The experiment was conducted in the Aquarium Room of the department. The aquaria were supplied with well aerated tap water and each tub was supplied by compressed air via-stone from aerator. Fresh tap water was stored in cuboidal tanks (of 400500 liters capacity) for 24 hours in order to dechlorinate the water. Each tub was cleaned every alternate day by siphoning fish feces and remaining feed.

The feed, normal or supplemented with earthworm extract was given at the rate of $2 \%$ of body weight.

\section{Antibacterial well diffusion assay}

The clear zone of inhibition was measured using a centimeter scale and the observations were recorded following Gram and Melchiorsen (1996).

\section{Histopathological examination}

Tissue samples obtained from intestine and kidney of experimental fish were fixed in Bouin's fixative for $24 \mathrm{~h}$. Following usual procedures, paraffin embedded sections were cut at 4-6 $\mu \mathrm{m}$ thickness and stained in Ehrlich Hematoxylin-Eosin. 


\section{Statistical analysis}

Data were analyzed using completely randomized design (CRD) following Snedecor and Cochran (1989).

\section{Results and Discussion}

Eight bacterial strains were reported and identified from Cyprinus carpio (Table 1). This is in agreement with the findings of other workers who have also shown that intestinal micro flora of aquatic animals consists of mainly Gram-negative aerobic, obligate anaerobic and facultative anaerobic bacteria and the composition of which may vary with environmental stresses (Ringo et al., 1997; Kennedy et al., 1998; Olafsen, 2001). Various bacterial strains that have been isolated from aquatic animals belonged to Aeromonas and Pseudomonas spp. and also some species of the family Enterobacteriaceae (Anand et al., 2011; Hassan et al., 2011; Satish et al., 2013).

The longevity of fish infected with different pathogenic bacteria is shown in table 2. The $A$. hydrophila appeared to be the most pathogenic bacterium among the isolated strains. As the fish injected with $A$. hydrophila survived for about 8 days post inoculation. Pseudomonas fluorescens and Staphylococcus aureus were also quite pathogenic as fish could survive just for about 10-11 days post inoculation and mortality was $80.25 \%$ (Table 2). A. hydrophila was found to be most pathogenic to fish as it took the least time to show the disease symptoms in fish (Sarkar and Rashid, 2012).

According to Harikrishnan et al., (2003) pathogenicity was induced by A. hydrophila when injected @ $10^{8} \mathrm{cfu} / \mathrm{ml}$ on $7^{\text {th }}$ day of injection and also reported hemorrhagic spots at the site of injection in common carp, whereas, in the present studies, similar symptoms appeared on the $4^{\text {th }}$ day of the injection in common carp.

\section{Antimicrobial well diffusion assay}

The results of the in vitro antagonism tests are shown in table 3. Maximum values of zone of inhibition against the fish bacterial pathogens were shown by Eisenia fetida in the composition of 1:1 (Extract: Ethanol).

The mean values of the zone of inhibition observed for Eisenia fetida against the Gram ve bacteria was $24.00 \mathrm{~mm}$ for $A$. hydrophila and against Gram+ve bacteria was $21.33 \mathrm{~mm}$ for S. aureus (Table 3, Fig. 1-6).

Similar to our findings, Vasanthi et al., (2013) found that extract of Eudrilus eugeniae at a dose of $100 \mu 1$ was able to inhibit the growth of S. aureus at a maximum level compared to other bacteria.

Present studies have revealed that earthworm extract possesses good antibacterial potency and these results are similar to other findings reported by other workers who have observed that coelomic fluid has antibacterial activity against bacteria (Mathur et al., 2010; Shobha and Kale, 2008; Kathireswari et al., 2014; Bansal et al., 2015, 2016).

Bhorgin and Uma (2014) also found that 95\% ethanol extract of earthworm showed potent antimicrobial agent against $A$. hydrophila and antifungal activity against $C$. albicans.

\section{Histopathological study}

The exposure of Cyprinus carpio to bacterial strains has revealed clear differences between the effect of pathogenic bacterium (A. hydrophila) infection and earthworm extract on treated groups.

No differences were observed in the histology of the foregut of the common carp treated with earthworm extract as it was similar to control fish as both had intact epithelial barrier. 
Table.1 List of bacteria isolated from infected/diseased fish

\begin{tabular}{|l|l|}
\hline Selective Media & Confirmation of bacteria \\
\hline Antibiotic Assay Medium No.38 & Pseudomonas aeruginosa \\
\hline Antibiotic Assay Medium. C & Staphylococcus aureus \\
\hline EMB medium & Enterobacter aerogens \\
\hline Hugh Leifson glucose medium & Micrococcus luteus \\
\hline Pseudomonas agar F Base & Pseudomonas fluorescence \\
\hline Rimler-Shotts Medium & Aeromonas hydrophila \\
\hline XLD (Xylose deoxycholate agar) EMB Agar (Eosin Methylene Blue Agar) & Shigella spp. \\
\hline
\end{tabular}

Table.2 Pathogenicity of bacteria and longevity of Cyprinus carpio

\begin{tabular}{|l|c|}
\hline Pathogenic bacteria & Longevity (in days) \\
\hline Gram negative & \\
\hline Aeromonas hydrophila & $8.66 \pm 0.33$ \\
\hline Escherichia coli & $12.14 \pm 0.57$ \\
\hline Enterobacter aerogens & $15.52 \pm 0.33$ \\
\hline Shigella spp. & $16.37 \pm 0.33$ \\
\hline Pseudomonas fluorescens & $11.53 \pm 1.20$ \\
\hline Pseudomonas aeruginosa & $13.70 \pm 0.57$ \\
\hline Gram positive & \\
\hline Micrococcus luteus & $13.25 \pm 0.33$ \\
\hline Staphylococcus aureus & $10.38 \pm 0.57$ \\
\hline CD (P<0.05) & 0.28 \\
\hline
\end{tabular}

All values are Mean \pm S.E of mean; $\mathrm{N}=30$ (10 fish $\times 3$ replications) 
Table.3 Inhibition zones (in mm) of Eisenia fetida against different pathogenic bacteria.

\begin{tabular}{|c|c|c|c|}
\hline \multirow[t]{2}{*}{ Bacterial strains } & \multicolumn{3}{|c|}{ Eisenia fetida } \\
\hline & $\begin{array}{l}\text { Pure Aqueous } \\
\text { Extract }\end{array}$ & $\begin{array}{c}\text { Aqueous Extract: Ethanol } \\
\qquad 1: 1\end{array}$ & $\begin{array}{l}\text { Aqueous Extract: Ethanol } \\
\qquad 1: 2\end{array}$ \\
\hline Aeromonas hydrophila & $21.33 \pm 0.33$ & $24.00 \pm 0.66$ & $21.33 \pm 0.57$ \\
\hline Staphylococcus aureus & $19.00 \pm 0.57$ & $21.33 \pm 0.57$ & $18.00 \pm 0.33$ \\
\hline Pseudomonas aeruginosa & $15.66 \pm 0.33$ & $18.00 \pm 0.33$ & $14.66 \pm 0.57$ \\
\hline Pseudomonas floresecens & $18.33 \pm 0.88$ & $20.33 \pm 0.57$ & $17.00 \pm 0.33$ \\
\hline Micrococcus luteus & $14.00 \pm 0.57$ & $16.00 \pm 0.66$ & $11.33 \pm 0.57$ \\
\hline Escherichia coli & $19.33 \pm 0.66$ & $21.00 \pm 0.33$ & $17.66 \pm 0.57$ \\
\hline Enterobacter aerogens & $18.33 \pm 0.33$ & $18.66 \pm 0.66$ & $15.33 \pm 0.33$ \\
\hline Shigella spp. & $11.66 \pm 0.33$ & $15.33 \pm 0.33$ & $11.66 \pm 0.33$ \\
\hline
\end{tabular}

All values are Mean \pm S.E of mean; $\mathrm{N}=30$ (10 fish $\times 3$ replications 


\section{Preparation of feed}

\begin{tabular}{|l|c|}
\hline Components & Amount in \% \\
\hline Soya Flour & 16.5 \\
\hline $\begin{array}{l}\text { Ground nut oil cake } \\
\text { (GNOC) }\end{array}$ & 16.5 \\
\hline Rice Bran & 17.0 \\
\hline Fish meal & 16.5 \\
\hline Sesame oil cake & 16.5 \\
\hline Tapioca flour & 16.5 \\
\hline MPA & 0.5 \\
\hline
\end{tabular}

Fig.1 Histological study of intestine in control group (40X)

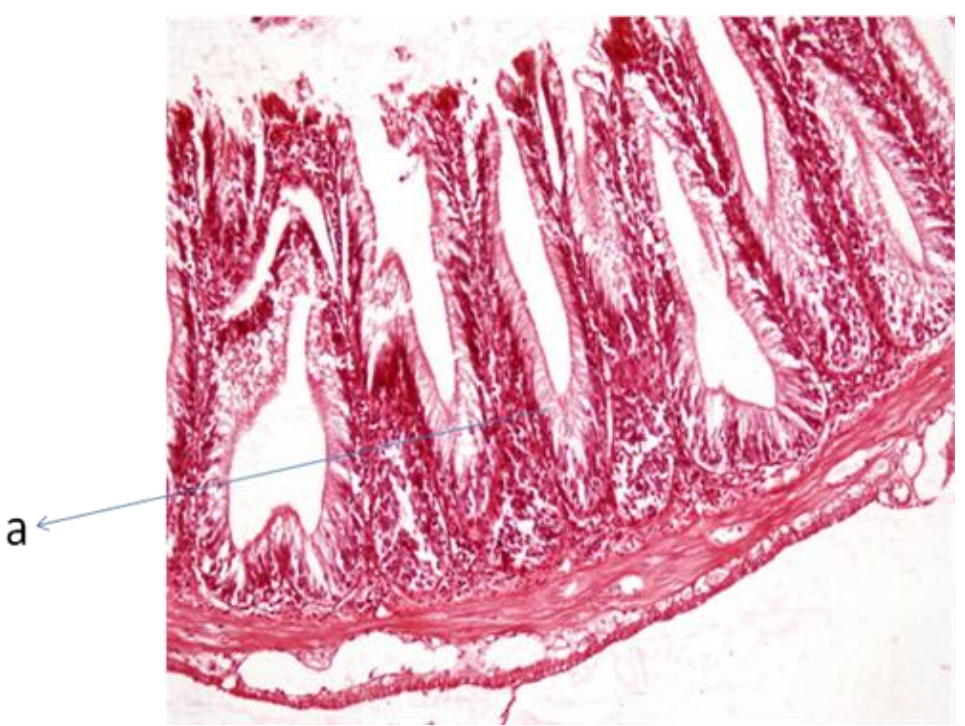

a) Intact or normal intestinal epithelium

Fig.2 ( $a$ and b). Histological changes in intestine in fish inoculated with pathogenic bacterium $(10 \mathrm{X})$. a) Fusion of microvilli of intestine along with infiltration of MNC's

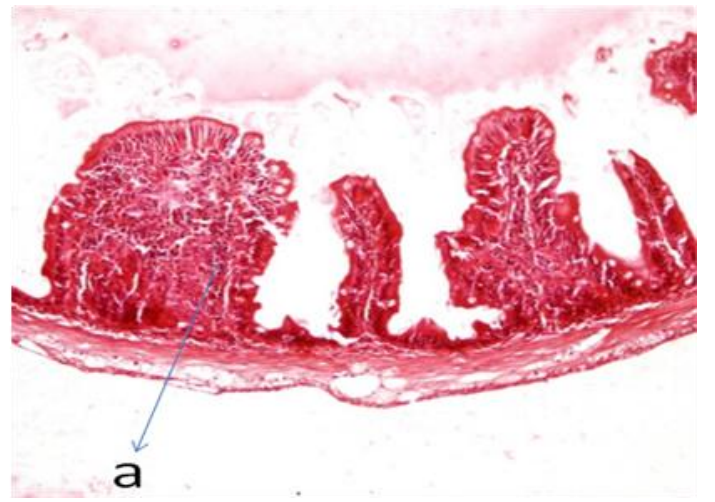

Fig.2 (a)

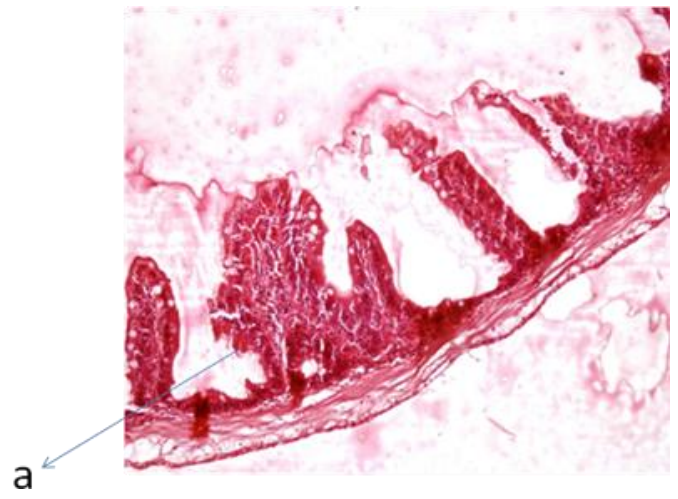

Fig.2 (b) 
Fig.3 Histological changes in intestine in fish fed with Earthworm extract (40X)

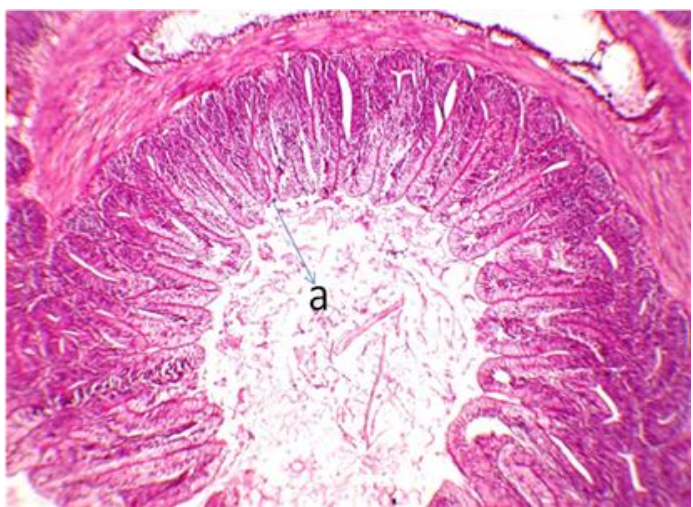

Fig.4 Histological study of kidney in control group (10X)

a) Melano-macrophage center, b) Haemopoeitic tissue, c) Tubules of kidney

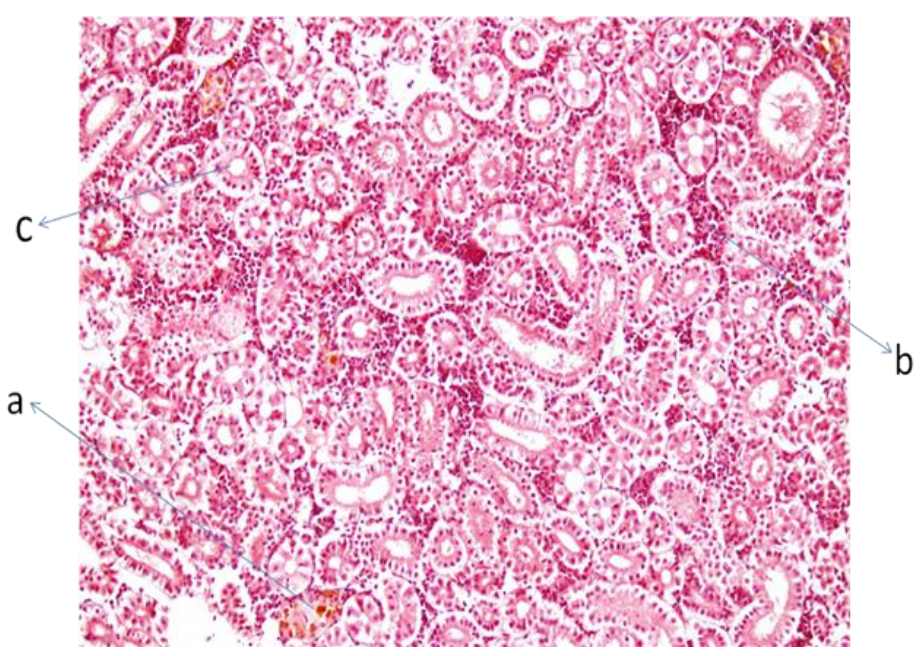

Fig.5 Histological changes in kidney in fish inoculated with pathogenic bacterium (10X)

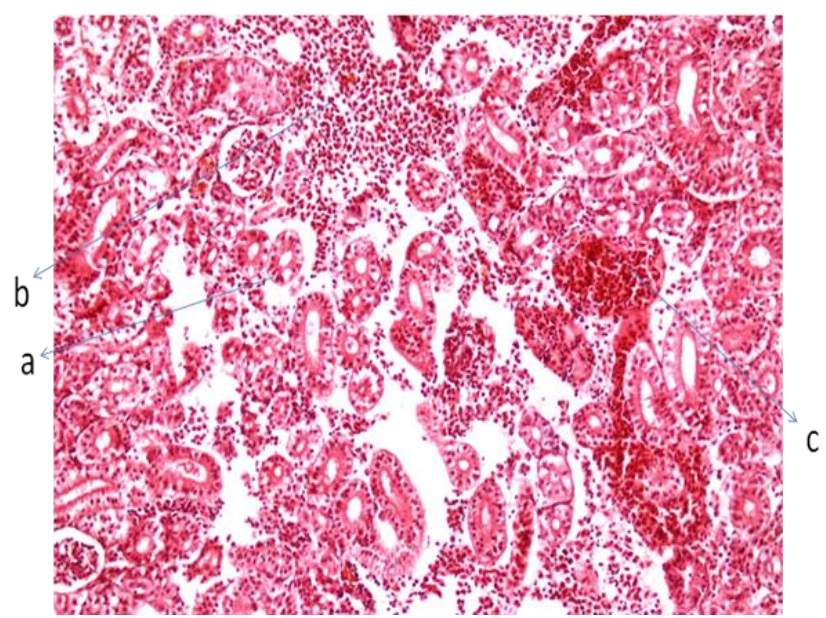

a) Vacuolation and degeneration of tubule epithelium, b) Infiltration of MNC's c) Haemorrhage 
Fig.6 Histological changes in kidney in fish fed with earthworm extract (10X)

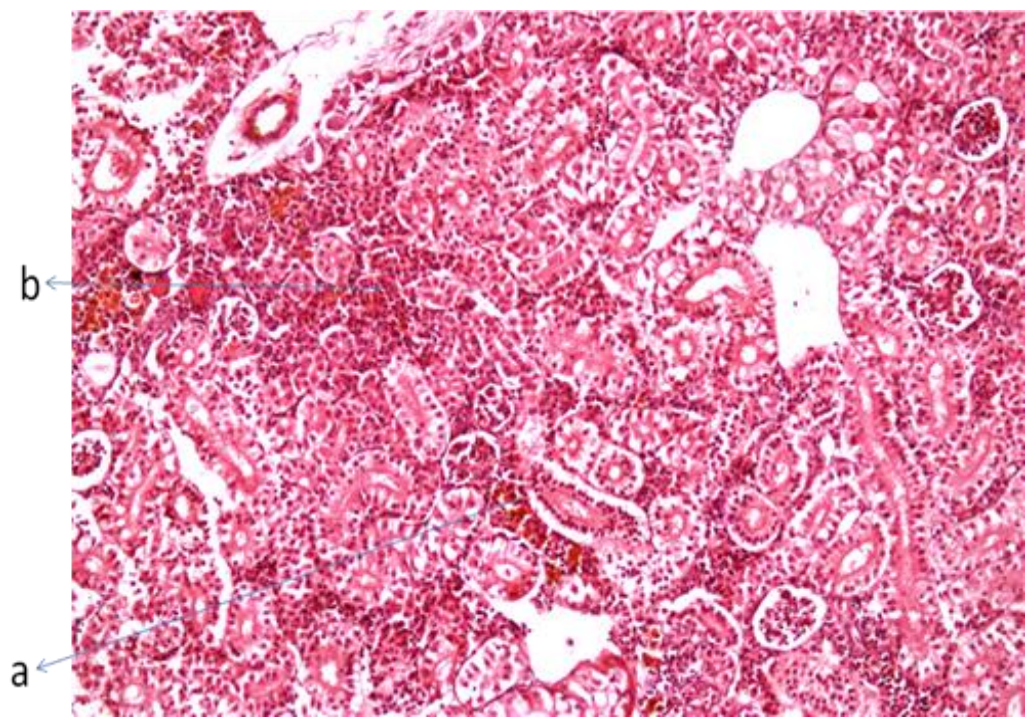

a) Increased Melano-macrophage centres, b) Haemopoeitic tissue c) Mild hyaline tubular casts of kidney

Fish infected with A. hydrophila showed severe enteritis in intestine characterized by degeneration and desquamation of epithelium in villi along with infiltration of mono-nuclear cells (Fig. 2). Similarly, severe changes were also observed in the histology of kidney where severe vacoulation and degeneration of tubular epithelium along with infiltration of mono-nuclear cells were observed. Hemorrhages were also observed in the parenchyma of the kidney (Fig. 5). Exposure of the foregut to the pathogenic bacterium (A. hydrophila) resulted in various damaging effects i.e. altered microvilli and protruding epithelial cells sloughing into the lumen, and the presence of cell debris in the gut lumen.

In the treatment, where the fish were injected with bacteria and fed on a diet incorporated with earthworm extract showed slight degeneration and desquamation of the intestinal villi epithelium and infiltration of mono-nuclear cells in intestine (Fig. 3). The increase in number of folds in the intestine caused by earthworm extract is definitely a beneficial effect on the host. In kidney, increased concentration of melano macrophage centre, haemopoeitic tissue with presence of mild hyaline tubular casts (Fig. 6) were observed. No histopathological changes were observed in intestine and kidney in the control group (Fig. 1 and 4). Similar findings were observed by Fatma Mohammad (2009), who worked on histopathological study of Tilapia zilli and S. vulgaris also observed that most common lesions in liver were vacuolar degeneration and kidney showed severe degenerative and necrotic changes in renal tubules with focal areas of necrosis and haemorrhage, haemolysis and vacuolar degeneration of renal tubules. In the kidney, necrosis of tubular epithelium in kidney with focal lymphocyte infiltration was considered to be associated with interstitial nephritis which seemed to be parallel with previous studies (Errer, 1981; Roberts, 2001; Hassan et al., 2008).

Present studies had clearly revealed that the earthworm extract is very effective in controlling the fish diseases in order to improve their health status. The present study further showed that fish treated with earthworm extract showed an improvement in the histopathology of common carp. The exposure of Cyprinus carpio to bacterial 
strains has revealed clear differences between the effect of pathogenic bacterium (A. hydrophila) infection and earthworm extract on treated groups. In conclusion, it can be stated that earthworm extract can reduce the incidence and duration of diseases. The application of earthworm extract in aquaculture shows promise but needs considerable efforts of research. A new approach method, that is gaining acceptance within the industry, is the use of earthworm extract to control potential pathogens.

\section{Acknowledgement}

The authors are thankful to Professor \& Head, Department of Zoology, College of Basic Sciences \& Humanities, CCSHAU, Hisar for providing facilities and support rendered. The author also thankful to Professor \& Head, Department of Veterinary Pathology, LUVAS, Hisar for providing necessary facilities for histopathological study.

\section{References}

Akinbowale, O. L., Peng, H. and Barton, M. D. (2006). Antimicrobial resistance in bacteria isolated from aquaculture sources in Australia. J. App. Microbiol. 100: 1103-1113.

Anand, J., Thomas, A. Akhila and Salini, M. P. (2011). Fluctuations in the microbial load at certain nonspecific Immune sites of macrobrachium rosenbergii supplemented with ocimum sanctum. The Ecoscan. 1: 389-392.

Ansari, A.A. and Sitaram, K. (2010). An investigation on the anti-microbial and anti-fungal properties of earthworm powder obtained from Eisenia foetida. Int. J. microbio. res. 1(2): 62-66.

Bachere, E., Mialhe, E., Noël, D., Boul, V., Morvan, A. and Rodrigues, J. (1995). Knowledge and research prospects in marine mollusc and crustacean immunology. Aquacult. 132: 17-32.

Bader, J.A., Shoemaker, C.A. and Klesius, P.H. (2003). Rapid detection of columnaris disease in channel catfish (ktalurus punctatus) with a new species specific 16S rRNA gene based PCR primer for Flavobacterium columnare. $J$ Microbiol. Met. 52 (2): 209-219.

Balamurugan, M., Parthasarathi, K., Cooper E.L. and Ranganathan, L.S. (2007). Earthworm paste (Lampito mauritii, Kinberg) alters inflammatory, oxidative, haematological and serum biochemical indices of inflamed rat, European Review for Medical and Pharmacological Sciences. 11: 77-90.

Balamurugan, M., Parthasarathi, K., Cooper E.L. and Rangnathan, L.S. (2009). Antiinflammatory and anti-pyretic activities of earthworm extract- Lampito mauritti (Kinberg). J. Ethnopharm. 121(2): 330332.

Bansal Nitish, Gupta, R.K. and Shashank. (2016). Antimicrobial Activity of Earthworm Extract, Eudrilus eugeniae against Fish Bacterial Pathogens. The Ecoscan. 10 (1\&2): 1-6.

Bansal Nitish, R.K.Gupta, Dharambir Singh and Shashank. (2015). Comparative study of antibacterial activity of two different earthworm species, Perionyx excavatus and Pheretima

posthumaagainst pathogenic bacteria. Journal of Applied and Natural Science. 7(2): 666-671

Bhorgin, A.J. and Uma, K. (2014). antimicrobial activity of earthworm powder (Lampito mauritii). Int.J.Curr.Microbiol.App.Sci. 3(1): 437443

Cooper, E.L. and Balamurugan, M. (2010). Unearthing a source of medicinal molecules. J. Ethnopharm. 10: 70-76.

Errer, H. (1981): The investigation of the pathologic findings of experimental 
Aeromonas hydrophila infection (Bacterial Haemorrhagic Septicaernia) in carp. Doktora Tezi, Ankara Üniversitesi

Fatma A.S. Mohamed. (2009). Histopathological Studies on Tilapia zillii and Solea vulgaris from Lake Qarun, Egypt. World Journal of Fish and Marine Sciences. 1 (1): 29-39.

Gerhardt, P., Murray, R.G.E., Wood, W.A. and Kreig, N.R. (1994). Methods for general and molecular bacteriology. American society for microbiology press, Washington, DC.

Gómez R, Balcázar J. L and Shen M. A. (2007). Probiotics as Control Agents in Aquaculture. J. Ocean Uni. China, 6(1): 76-79.

Gram, L. and Melchiorsen, J. (1996). Interaction between fish spoilage bacteria Pseudomonas sp. and Shewanella putrefaciens in fish extracts and on fish tissue. J. Appl. Bacteriol. 80: 589-595.

Harikrishan, R., Nishrani, M. and Balasundaram, C. (2003). Heamatological and Biochemical parameters in common carp, Cyprinus carpio, following herbal treatment for Aeromonas hydrophila infection. Aquacult. 221(1-4): 41-50.

Hassan, M.A., Mamnur Rashid, M., Islam, M.A., Mostafa, K. and Islam, M.T. (2008). Histopathological studies of EUS affected shing Heteropneustes fossilis from a fish farm of Mymensingh. Bangladesh J Fish. Res. 12(1): 12-36.

Hassan, S., Qureshi, T. A., Ahmad, B. and Manohar, S. (2011). Microflora of ice in fish carrying crates from certain fish markets of bhopal. The Ecoscan. 5(1\&2): 81-83

Hrzenjak, T., Popovic, M., Bozic, T., Grdisa, M., Kobrehel, D. and Rudman, L. (1998). Fibrinolytic and anticoagulative activities from the earthworm Eisenia foetida. Comp. Biochem. and Physiol. 119: 825-832.

Ismail, S.A. (2005). The Earthworm Book. Other India Press, Apusa, Goa, pp: 101

John, S.A. and Packialakshmi, N. (2007). Studies on antimicrobial activity of Perionyx excavatus. Pakistan journal of biological sciences. 10(19): 3482-3484.

Joseph, A. and Clerk G. C. (2002). Infestation of fish-culturing communities with fishborne bacteria: The Ghanain case. Int. $J$. Environ. Health Res. 12(3): 277-282.

Kathireswari, P., Alakesan, A., Abirami, P. and Sangeetha, P. (2014). Antimicrobial activity of earthworm coelomic fluid against diseases causing microorganisms. Int.J.Curr. Microbiol. App. Sci 3(8): 608-613.

Kennedy, S. B., Tucker, J. W., Thoresen, M. and Sennett, D. G. (1998). Current methodology for the use of probiotic bacteria in the culture of marine fish larvae. Aquaculture 98, World Aqua. Soc., Baton Rouge. pp. 286.

Keskin, O., Secer, S., Izgor, M., Turkyilmaz, S. and Makaosya, R. S. (2004). Edwardsiella ictaluri Infection in Rainbow Trout (Oncorhynchus mykiss). J. Vet. Anim. sci. 28: 649-653.

Mathur, A., Satish K. Verma, Rakshanda Bhat, Santosh K. Singh, Archana Prakash, G.B.K.S. Prasad and V. K. Dua. (2010). Antimicrobial Activity of Earthworm Extracts. Int jou of Pharma Scie. 2(4): 364-370.

Olafsen, J. A. (2001). Interactions between fish larvae and bacteria in marine aquaculture. Aquacult. 200: 223-247.

Prakash, M., Balamurugan, M., Parthasarathi, K., Gunasekaran, G., Cooper E.L. and Ranganathan, L.S. (2007). Anti-ulceral and anti-oxidative properties of "earthworm paste" of Lampito mauritii (Kinberg) on Rattus norvegicus, 
European Review for Medical and Pharmacological Sciences 11: 9-15.

Ranganathan, L. S. (2006). Vermibiotechnology-From Soil Health to Human Health. Agrobios, Jodhpur, India.

Ringo, E., Olsen, R. E., Overli, O. and Lovik, F. (1997). Effect of dominance hierarchy formation on aerobic microbiota associated with epithelial mucosa of subordinate and dominant individuals of Arctic charr, Salvelinus alpinus (L.). Aquac. Res. 28: 901-904.

Roberts, R.J. (2001). Fish pathology. Third edition. Ed. By Roberts, R.J. W.B. Saunders. London, Edinburgh, New York- Philadelphia, St. Louis- Sydney. Toronto. 411pp.

Sarkar, M. J. A. and Rashid, M. M. (2012). Pathogenicity of the bacterial isolate Aeromonas hydrophila to catfishes, carps and perch. J. Bangladesh Agril. Univ. 10(1): 157-161.

Satish, P. V. V., Sree Rekha, N., Sunita, K., Somaiah, K. and Kanaka Raju, A. (2013). Prevalence of fin and tail rot disease in nursery ponds of guntur district, andhra pradesh, India. The Ecoscan. 7(3\&4): 95-99

Schwarz, S., Kehrenberg, C. and Walsh, T. R. (2001). Use of antimicrobial agents in veterinary medicine and food animal production. Intern. J. Antimicrob. Agent. 17: 431-437.

Shobha,S.V., and Kale, R.D. (2008). In vitro studies on control of soil-borne plant pathogens by earthworm Eudrilus eugeniae exudates. Green Pages. http://www.ecoweb.com/editorial/08010 6.html.

Snedecor, G. and Cochran, W. (1989). Statistical Methods (8th edition). The Iowa State University Press.

Thophon, S., M. Kruatrachuc, E. Upathau, P. Pokcthitiyook, S. Sahaphong and S. Jarikhuan, (2003). Histopathological alterations of white seabass, Lates calcarifer in acute and subchronic cadmium exposure. Environ. Pollut. 121: 307-320.

Vasanthi, K., Chairman, K. and Ranjit Singh, A.J.A. (2013). Antimicrobial activity of earthworm paste Eudrilus eugeniae. African journal of Environmental Science and Technology. 7(8): 789-793

Verschuere, L., Rombaut, G., Sorgeloos, P. and Verstraete, W. (2000). Probiotic bacteria as biological control agents in aquaculture. Microbiol. Molec. Biol. Rev. 64: 655-671

Wang, C., Sun, Z., Liu, Y., Zhang, X. and Xu, G. (2007). A novel antimicrobial vermipeptide family from earthworm Eisenia fetida. European journal of soil biology. 43: 127-134.

\section{How to cite this article:}

Nitish Bansal, Rajender Kumar Gupta and Vikas Nehra. 2018. Antibacterial Effects of Eisenia fetida, Earthworm Extract against Pathogenic Bacteria Isolated from Cyprinus carpio. Int.J.Curr.Microbiol.App.Sci. 7(04): 2329-2340. doi: https://doi.org/10.20546/ijcmas.2018.704.267 